\title{
Short communication: Supplementation of colostrum and milk with 5-hydroxy-L-tryptophan affects immune factors but not growth performance in newborn calves
}

\author{
Lorenzo E. Hernández-Castellano, ${ }^{* 1}$ Ranya Özçelik, ${ }^{*}$ Laura L. Hernandez, $†$ and Rupert M. Bruckmaier* \\ *Veterinary Physiology, Vetsuisse Faculty, University of Bern, 3012 Bern, Switzerland \\ †Department of Dairy Science, University of Wisconsin, Madison 53706
}

\begin{abstract}
In ruminants, colostrum is the main source of immunoglobulins for the newborn animal, conferring immune protection until the immune system becomes active and able to synthesize its own immunoglobulins. Serotonin (5-HT), a biogenic amine derived from tryptophan, has stimulatory effects on many physiological processes, including components of the innate (mastocytes, eosinophils, and natural killer cells) and adaptive ( $\mathrm{T}$ and $\mathrm{B}$ lymphocytes) immune systems. Based on the known effects of 5 -HT on the immune system, we hypothesized that increased concentrations of 5-HT, through administration of its precursor 5-hydroxy-L-tryptophan (5-HTP), may positively affect development of the calf's immune system and therefore support health and growth performance during the first weeks of life. Eighteen calves were randomly assigned to 1 of 2 experimental groups (control and 5-HTP), resulting in $\mathrm{n}=9$ per treatment group. Both groups received 2 colostrum meals from a common pool of colostrum. Thereafter, calves were fed milk replacer twice daily for $30 \mathrm{~d}$. In the 5 -HTP group, colostrum and milk replacer were supplemented with $1.5 \mathrm{mg}$ of $5-\mathrm{HTP} / \mathrm{kg}$ of birth weight during the first $15 \mathrm{~d}$ after birth. Body weight was recorded at birth and on d 5, 10, 15, and 30 after birth. Blood samples were collected every morning $(0800 \mathrm{~h})$ before feeding from birth until $\mathrm{d} 5$ and then on d 7, 9, 11, 13, 15, and 30 after birth. Serum 5 -HT concentrations were increased as a consequence of the 5-HTP supplementation. Plasma immunoglobulin $\mathrm{G}$ concentrations did not differ between groups throughout the experimental period. The blood mRNA abundance of several factors related to the innate and adaptive immune system [nuclear factor kappa-lightchain-enhancer of activated $B$ cells $(\mathrm{NF}-\kappa \mathrm{B})$, serum amyloid A-1 (SAA1), chemokine C-C motif ligand 5
\end{abstract}

Received July 14, 2017.

Accepted August 31, 2017.

${ }^{1}$ Corresponding author: lorenzo.hernandez@vetsuisse.unibe.ch
(CCL5), cyclooxygenase 2 (PTGS2), haptoglobin (HP), and IL-1 $\beta$ ] were increased in calves supplemented with 5-HTP. Supplementation of 5-HTP did not affect any of the measured metabolites (fatty acids and glucose) or minerals (calcium and magnesium) or milk feed intake, feed conversion ratio, and growth. In conclusion, 5-HTP supplementation induced an increase of 5 -HT concentrations in blood and caused an increase in mRNA abundance of several factors related to the innate and adaptive immune systems, which might increase the protection of the calf against external agents. Key words: serotonin, calves, immune system, colostrum

\section{Short Communication}

The first few days after birth are among the most critical in the life of the calf, in which morbidity and mortality are the greatest (Mee, 2013). In ungulates, the transfer of immunoglobulins from the dam to the fetus through the placenta is limited. Therefore, colostrum is the main source of immunoglobulins in these species, providing immune protection until the immune system of the newborn animal becomes active and efficient (Erhard et al., 1999; Baumrucker and Bruckmaier, 2014; Hernández-Castellano et al., 2015b). Colostrum contains a complex mixture of proteins that actively participate in the protection of the neonate against pathogens and other postpartum environmental challenges (Blum and Hammon, 2000; Bendixen et al., 2011; Hernández-Castellano et al., 2015a), with IgG being the most abundant bioactive component (Butler, 1973; Hernández-Castellano et al., 2016). Serotonin (5-hydroxytryptamine, $\mathbf{5 - H T}$ ) is a neurotransmitter synthesized from 5-hydroxy-L-tryptophan (5-HTP), a hydroxylated derivative of the amino acid tryptophan, which contributes to the regulation of physiological processes in the central nervous system such as those related to mood or appetite. Most of the peripheral 5 -HT is synthesized by the enterochromaffin cells in the gut (Gershon et al., 1965); however, 5-HT is also 
synthesized by mammary epithelial cells (Hernandez et al., 2009) and by platelets (Lesurtel et al., 2006). Peripheral 5-HT participates in many physiological processes including calcium homeostasis (Weaver et al., 2016; Hernández-Castellano et al., 2017a) and the modulation of glucose and lipid metabolism (Sugimoto et al., 1990; Watanabe et al., 2014; Laporta et al., 2015). Additionally, 5-HT is involved in regulating several pathways of the innate immune system including the adhesion and chemotaxis of mastocytes in humans and mice (Kushnir-Sukhov et al., 2006), the chemotaxis of eosinophils in humans (Boehme et al., 2004), and the stimulation of cytolytic activity and proliferation of natural killer cells in humans (Evans et al., 2008; Hernandez et al., 2010). Serotonin also affects the adaptive immune system by stimulating the proliferation of $\mathrm{T}$ and B lymphocytes (Serafeim et al., 2002; León-Ponte et al., 2007). Based on the diverse effects of 5 - $\mathrm{HT}$ on the immune system, we hypothesized that supplementation of colostrum and milk with 5-HTP may positively affect development of the calf's immune system and affect diverse metabolic pathways during the first weeks of life.

The present study was approved by the Cantonal Committee on Animal Experiments (Canton of Fribourg, Switzerland) and all experimental procedures followed Swiss law of animal protection. Eighteen newborn singleton dairy calves from the experimental herd of the Agroscope Institute for Livestock Science research farm (Posieux, Switzerland) were used in this study. At birth (d 0), animals were randomly assigned to 1 of 2 experimental groups: control and 5-HTP). During the first $2 \mathrm{~h}$ after birth, calves were dried, weighed, and ear tagged. Both groups were bottle-fed from a common pool of bovine colostrum containing $13.47 \%$ protein, $4.92 \%$ fat, $3.01 \%$ lactose, and a total IgG concentration of $53.7 \mathrm{mg} / \mathrm{mL}$. Colostrum chemical composition was determined at the Suisselab AG Zollikofen (Zollikofen, Switzerland). The total IgG concentration in the pool of colostrum was measured using a commercial ELISA kit specific to bovine IgG (Bethyl Laboratories, Montgomery, TX). Each animal received $4 \mathrm{~L}$ of colostrum equally divided in 2 colostrum meals at 2 and $12 \mathrm{~h}$ after birth $(2 \mathrm{~L} / \mathrm{meal})$. After the 2 colostrum meals, calves in both groups were fed using nipple buckets twice daily (0800 and $1800 \mathrm{~h}$ ) with a commercial milk replacer, at $16 \%$, specially formulated for calves (UFA 207 plus, UFA, Herzogenbuchsee, Switzerland; 95.5\% DM, 23.6\% $\mathrm{CP}$, and $22.7 \%$ fat, air-dry powder basis) until d 30 after birth. In each meal, calves were fed until refusal, when the remaining milk replacer was measured and discarded. Colostrum and milk replacer for the 5-HTP group were supplemented with $1.5 \mathrm{mg}$ of $5-\mathrm{HTP} / \mathrm{kg}$ of birth weight during the first $15 \mathrm{~d}$ following birth. From birth to d 15 after birth, daily individual feed intake was recorded. From d 15 to 30, both groups were fed with the same milk replacer without 5-HTP supplementation. Body weight was recorded at birth and on d 5, 10, 15, and 30 after birth. Calves were housed in individual calf hutches, providing a covered space of $1.7 \times 1.20 \times 1.50 \mathrm{~m}$ and an uncovered space of 1.50 $\times 1.50 \times 1.50 \mathrm{~m}$. Animal health status was monitored during the experimental period (for diarrhea, parasites, or fever), and all animals were found to be healthy throughout the experimental period.

Blood samples were collected every morning (0800 h) before feeding from birth through d 5 and then on d 7 , 9, 11, 13, 15, and 30 after birth. Blood samples were taken by puncture from the jugular vein using vacuum tubes for serum and plasma (containing $\mathrm{K}_{3}$-EDTA) collection. After sampling, tubes were stored either on wet ice for $15 \mathrm{~min}$ (plasma tubes) or at room temperature for $2 \mathrm{~h}$ (serum tubes) and then centrifuged at 2,500 $\times$ $g$ for $20 \mathrm{~min}$ at $4^{\circ} \mathrm{C}$. Plasma and serum were then aliquoted and stored at $-80^{\circ} \mathrm{C}$. Additional blood samples for RNA isolation were collected at birth (d 0) and on d 15 and 30 after birth using PAXgene blood RNA tubes (PreAnalytiX, Hombrechtikon, Switzerland). After sampling, the tubes were stored at $4^{\circ} \mathrm{C}$ for $12 \mathrm{~h}$, stored at $-20^{\circ} \mathrm{C}$ for $24 \mathrm{~h}$, and finally stored at $-80^{\circ} \mathrm{C}$ until RNA extraction. The concentration of $\operatorname{IgG}_{1}$ and $\operatorname{IgG}_{2}$ in plasma was measured using commercial ELISA kits specific to bovine $\operatorname{IgG}_{1}$ and $\operatorname{IgG}_{2}$, respectively (Bethyl Laboratories) with some modifications as described by Lehmann et al. (2015). Glucose and fatty acids (FA) plasma concentrations were measured using commercial kits from Randox (GL364 and FA115, respectively; Randox Laboratories Ltd., Schwyz, Switzerland). Total serum calcium concentrations were determined using a commercial kit from Diatools (DIA00461, Diatools AG, Villmergen, Switzerland). Serum magnesium concentrations were determined using a commercial kit from Randox (MG531, Randox Laboratories Ltd.). Serum serotonin concentrations were determined using a commercial 5-HT ELISA kit (IM1749, Beckman Coulter GmbH, Sinsheim, Germany). Extraction of total RNA was performed using PAXgene Blood RNA kit (PreAnalytiX) according to the manufacturer's instructions. The purity and quantity of RNA was measured using a NanoDrop ND-2000 spectrophotometer (NanoDrop Technologies Inc., Wilmington, DE). Reverse transcription of $1 \mu \mathrm{g}$ of total RNA was performed with the RNA-dependent DNA polymerase Moloney Murine Leukemia Virus Reverse Transcriptase RNase H Minus, Point Mutant (MMLV-RT; Promega Corp., Madison, WI) and random hexamer primers (Invitrogen, Leek, the Netherlands). The mRNA abundance of housekeeping genes (GAPDH and ubiquitin) and target genes 
Table 1. Blood mRNA expression in control calves and calves supplemented with 5-hydroxy-L-tryptophan $(5$-HTP $)$ at birth $(\Delta \mathrm{d} 0)$ and the relative changes on $\mathrm{d} 15(\Delta \mathrm{d} 15-\Delta \mathrm{d} 0)$; values represent mean \pm SEM

\begin{tabular}{|c|c|c|c|c|}
\hline Variable $^{1}$ & Group & $\Delta \mathrm{d} 0$ & $\Delta \mathrm{d} 15-\Delta \mathrm{d} 0$ & $\begin{array}{c}\text { ANOVA }^{2} \\
P \text {-value: } \\
\Delta \mathrm{d} 15-\Delta \mathrm{d} 0\end{array}$ \\
\hline \multirow[t]{2}{*}{$\mathrm{HP}$} & Control & $13.00 \pm 0.23$ & $0.02 \pm 0.24$ & 0.04 \\
\hline & 5-НTP & $12.98 \pm 0.27$ & $1.20 \pm 0.30^{*}$ & \\
\hline \multirow[t]{2}{*}{ PTGS2 } & Control & $6.91 \pm 0.32$ & $-0.03 \pm 0.18$ & 0.92 \\
\hline & 5-HTP & $6.89 \pm 0.27$ & $-0.06 \pm 0.21$ & \\
\hline \multirow[t]{2}{*}{ IL-1 $\beta$} & Control & $11.21 \pm 0.61$ & $-0.20 \pm 0.21$ & 0.03 \\
\hline & 5-НTP & $11.33 \pm 0.45$ & $0.82 \pm 0.32^{*}$ & \\
\hline \multirow[t]{2}{*}{ IL-8 } & Control & $11.00 \pm 0.44$ & $-1.26 \pm 0.40^{*}$ & 0.12 \\
\hline & 5-HTP & $10.75 \pm 0.63$ & $-0.62 \pm 0.50^{*}$ & \\
\hline \multirow{2}{*}{ IL-10 } & Control & $6.73 \pm 0.23$ & $-1.33 \pm 0.16^{*}$ & 0.21 \\
\hline & 5-HTP & $6.57 \pm 0.20$ & $-1.56 \pm 0.29^{*}$ & \\
\hline \multirow[t]{2}{*}{ TNFA } & Control & $7.65 \pm 0.21$ & $0.92 \pm 0.38^{*}$ & 0.71 \\
\hline & 5-НTP & $8.02 \pm 0.39$ & $0.80 \pm 0.34^{*}$ & \\
\hline \multirow[t]{2}{*}{ IFN- $\alpha$} & Control & $6.82 \pm 0.12$ & $-0.34 \pm 0.33$ & 0.83 \\
\hline & 5-НTP & $6.82 \pm 0.15$ & $-0.29 \pm 0.20$ & \\
\hline \multirow[t]{2}{*}{ IFN- $\beta$} & Control & $6.56 \pm 0.16$ & $-0.42 \pm 0.17$ & 0.06 \\
\hline & 5-HTP & $6.49 \pm 0.16$ & $0.14 \pm 0.11$ & \\
\hline \multirow[t]{2}{*}{ SAA1 } & Control & $7.30 \pm 0.98$ & $1.23 \pm 0.44$ & 0.66 \\
\hline & 5-HTP & $7.21 \pm 1.70$ & $2.21 \pm 0.81$ & \\
\hline \multirow[t]{2}{*}{ CCL5 } & Control & $11.31 \pm 0.14$ & $1.03 \pm 0.53$ & 0.81 \\
\hline & 5-HTP & $11.12 \pm 0.29$ & $1.05 \pm 0.36^{*}$ & \\
\hline \multirow[t]{2}{*}{ NF-kB } & Control & $10.64 \pm 0.15$ & $0.60 \pm 0.16$ & 0.99 \\
\hline & 5-HTP & $10.71 \pm 0.15$ & $0.42 \pm 0.13$ & \\
\hline
\end{tabular}

related to the innate and adaptive immune systems (Tables 1 and 2) was measured by real-time quantitative PCR in a Rotor-Gene 6000 rotary analyzer (Corbett Research, Sydney, Australia) using the software version 1.7.75. The cycle threshold values (CT) from the candidate genes were normalized according the mean of the housekeeping gene CT.

Results are presented as means \pm SEM. Statistical analyses were performed using SAS software (version 9.4, SAS Institute Inc., Cary, NC) by a linear mixed model with repeated measures (MIXED procedure). The final model included treatment (control vs. 5-HTP), experimental period (from birth to d 30 after birth), and the interaction between both as dependent variables. Calf was included as a repeated subject, and birth (d 0 ) was included as a covariate. Significant differences between groups were localized by Tukey-Kramer test. Values were considered significant when $P<0.05$.

In calves receiving the 5-HTP supplementation, serum 5-HT concentrations (Figure 1A) did not change until d $6(P>0.05)$ but were increasing on $\mathrm{d} 7(P<$ 0.05). Serotonin concentrations remained elevated until d 15 and decreased on d $30(P<0.05)$. In control calves, 5-HT concentrations decreased during the first day after birth $(P<0.05)$, increasing thereafter from $\mathrm{d}$ 5 to $30(P<0.05)$. On d 30,5 -HT concentrations were similar to those measured at birth $(P>0.05)$. Serum 5 -HT concentrations did not differ between groups at birth $(P>0.05)$. From d 1 to 15, 5-HT concentrations were considerably higher in 5-HTP calves than in controls $(P<0.05)$. No differences in 5 -HT concentrations were observed between groups on d $30(P>0.05)$.

Plasma $\operatorname{IgG}_{1}$ (Figure $1 \mathrm{~B}$ ) and $\mathrm{IgG}_{2}$ (Figure $1 \mathrm{C}$ ) concentrations were below the detection limit in both groups at birth ( $\mathrm{IgG}_{1}$ detection limit: $18.8 \mathrm{ng} / \mathrm{mL}, \operatorname{IgG}_{2}$ detection limit: $12.5 \mathrm{ng} / \mathrm{mL}$ ) and therefore were not used for any statistical evaluation. In both groups, $\operatorname{IgG}_{1}$ concentrations were increased on $\mathrm{d} 1(P<0.05)$ when the concentrations were the highest in both groups $(P$ $<0.05)$. Plasma $\operatorname{IgG}_{1}$ concentrations decreased progressively in both groups until d $30(P>0.05)$. No differences in $\mathrm{IgG}_{1}$ concentrations were observed between groups during the experimental period $(P>0.05)$. Similarly to $\operatorname{IgG}_{1}, \mathrm{IgG}_{2}$ concentrations increased on $\mathrm{d}$ $1(P<0.05)$ in both groups when the concentrations were the highest $(P<0.05)$. Plasma $\operatorname{IgG}_{2}$ concentrations decreased in both groups until d $30(P<0.05)$. No differences in $\operatorname{IgG}_{2}$ concentrations were observed between groups during the experimental period $(P>$ $0.05)$.

As shown in Tables 1 and 2, the mRNA abundance of haptoglobin (HP) and IL-1 $\beta$ increased on d 15, and 
that of cyclooxygenase 2 (PTGS2) on d 30 in animals receiving the 5-HTP supplementation compared with controls $(P<0.05)$. In both groups, mRNA abundance in blood of IL-8 and IL-10 decreased on d 15 and 30. Similarly, the mRNA abundance of tumor necrosis factor $\alpha$ (TNFA) increased on d 15 and 30 in both groups $(P<0.05)$. Additionally, exclusively in calves supplemented with 5-HTP, the mRNA abundance of HP and chemokine C-C motif ligand 5 (CCL5) increased in blood on d $15(P<0.05)$ as did PTGS2, serum amyloid A-1 (SAA1), CCL5 and nuclear factor kappa-lightchain-enhancer of activated B cells $(\mathbf{N F}-\mathbf{k B})$ on d 30 $(P<0.05)$.

No significant differences in FA, glucose, calcium, or magnesium concentrations were observed between groups during the entire studied period $(P>0.05)$. Fatty acid, calcium, and magnesium concentrations were the highest at birth $(0.56 \pm 0.09 \mathrm{mmol} / \mathrm{L}, 2.83 \pm$ $0.11 \mathrm{mmol} / \mathrm{L}$, and $0.83 \pm 0.04 \mathrm{mmol} / \mathrm{L}$, respectively) and decreased progressively thereafter $(P<0.05)$. Lowest values were reached for FA on d $30(0.11 \pm 0.02$ $\mathrm{mmol} / \mathrm{L})$, for calcium on d $11(2.51 \pm 0.15 \mathrm{mmol} / \mathrm{L})$, and for magnesium on d $3(0.75 \pm 0.04 \mathrm{mmol} / \mathrm{L})$ (all $P<0.05)$. Glucose concentrations increased from birth $(3.51 \pm 0.41 \mathrm{mmol} / \mathrm{L})$ to $\mathrm{d} 3(5.84 \pm 0.26 \mathrm{mmol} / \mathrm{L} ; P$
$<0.05)$. No further differences were observed until the end of the experimental period.

No significant differences were observed in milk replacer intake, feed conversion ratio, ADG, or BW between groups $(P>0.05)$. Milk replacer intake increased from d $1(3.55 \pm 0.35 \mathrm{~L})$ to $\mathrm{d} 4(6.95 \pm 0.85 \mathrm{~L} ; P<$ $0.05)$; thereafter, similar feed intake was recorded until d $30(9.65 \pm 1.85 \mathrm{~L})$. Feed conversation ratio (g of milk replacer/g of gain) increased from $0.79 \pm 0.08$ (recorded from birth to d 5) to $1.70 \pm 0.18$ (recorded from d 15 to $30 ; P<0.05$ ). Average daily gain increased from $345.52 \pm 37.32 \mathrm{~g}$ of $\mathrm{BW} / \mathrm{d}$ (recorded from birth to d 5) to $621.57 \pm 42.48 \mathrm{~g}$ of $\mathrm{BW} / \mathrm{d}$ (recorded from d 5 to 10 ); thereafter, similar ADG was recorded until the end of the experimental period $(768.28 \pm 49.52 \mathrm{~g}$ of $\mathrm{BW} / \mathrm{d} ; P$ $<0.05)$. Body weight constantly increased from birth $(42.93 \pm 2.34 \mathrm{~kg})$ to d $30(63.18 \pm 1.98 \mathrm{~kg} ; P<0.05)$.

5 -Hydroxy-L-tryptophan has been used to increase blood 5-HT concentrations in humans (Gendle et al., 2013; Sauer et al., 2014), mice (Yamada et al., 2006; Laporta et al., 2013), and cows (Weaver et al., 2016; Hernández-Castellano et al., 2017a,b). In contrast to the native amino acid tryptophan, 5-HTP is used exclusively for 5-HT synthesis because it cannot be used in any other metabolic pathway. In the present study,

Table 2. Blood mRNA expression in control calves and calves supplemented with 5-hydroxy-L-tryptophan $(5$-HTP $)$ at birth $(\Delta \mathrm{d} 0)$ and the relative changes on $\mathrm{d} 30(\Delta \mathrm{d} 30-\Delta \mathrm{d} 0)$; values represent mean \pm SEM

\begin{tabular}{|c|c|c|c|c|}
\hline Variable $^{1}$ & Group & $\Delta \mathrm{d} 0$ & $\Delta \mathrm{d} 30-\Delta \mathrm{d} 0$ & $\begin{array}{c}\text { ANOVA }^{2} \\
P \text {-value: } \\
\Delta \mathrm{d} 30-\Delta \mathrm{d} 0\end{array}$ \\
\hline \multirow[t]{2}{*}{$\overline{\mathrm{HP}}$} & Control & $13.00 \pm 0.23$ & $-0.92 \pm 0.33$ & 0.97 \\
\hline & 5-HTP & $12.98 \pm 0.27$ & $-0.94 \pm 0.33$ & \\
\hline \multirow[t]{2}{*}{ PTGS2 } & Control & $6.91 \pm 0.32$ & $-0.06 \pm 0.21$ & 0.01 \\
\hline & 5-HTP & $6.89 \pm 0.27$ & $0.95 \pm 0.18^{*}$ & \\
\hline \multirow[t]{2}{*}{ IL-1 $\beta$} & Control & $11.21 \pm 0.61$ & $0.22 \pm 0.29$ & 0.87 \\
\hline & 5-HTP & $11.33 \pm 0.45$ & $-0.10 \pm 0.46$ & \\
\hline \multirow[t]{2}{*}{ IL-8 } & Control & $11.00 \pm 0.44$ & $-1.89 \pm 0.35^{*}$ & 0.60 \\
\hline & 5-HTP & $10.75 \pm 0.63$ & $-1.71 \pm 0.49^{*}$ & \\
\hline \multirow[t]{2}{*}{ IL-10 } & Control & $6.73 \pm 0.23$ & $-1.24 \pm 0.27^{*}$ & 0.29 \\
\hline & 5-HTP & $6.57 \pm 0.20$ & $-1.17 \pm 0.24^{*}$ & \\
\hline \multirow[t]{2}{*}{ TNFA } & Control & $7.65 \pm 0.21$ & $1.19 \pm 0.28^{*}$ & 0.86 \\
\hline & 5-НTP & $8.02 \pm 0.39$ & $1.02 \pm 0.35^{*}$ & \\
\hline \multirow{2}{*}{ IFN- $\alpha$} & Control & $6.82 \pm 0.12$ & $-0.12 \pm 0.22$ & 0.94 \\
\hline & 5-HTP & $6.82 \pm 0.15$ & $-0.58 \pm 0.25$ & \\
\hline \multirow[t]{2}{*}{ IFN- $\beta$} & Control & $6.56 \pm 0.16$ & $0.46 \pm 0.11$ & 0.78 \\
\hline & 5-HTP & $6.49 \pm 0.16$ & $0.56 \pm 0.15$ & \\
\hline \multirow{2}{*}{ SAA1 } & Control & $7.30 \pm 0.98$ & $1.75 \pm 0.54$ & 0.70 \\
\hline & 5-HTP & $7.21 \pm 1.70$ & $2.53 \pm 0.48^{*}$ & \\
\hline \multirow[t]{2}{*}{ CCL5 } & Control & $11.31 \pm 0.14$ & $0.97 \pm 0.50$ & 0.57 \\
\hline & 5-HTP & $11.12 \pm 0.29$ & $1.12 \pm 0.21^{*}$ & \\
\hline \multirow{2}{*}{ NF-kB } & Control & $10.64 \pm 0.15$ & $0.52 \pm 0.19$ & 0.10 \\
\hline & 5-HTP & $10.71 \pm 0.15$ & $0.79 \pm 0.11^{*}$ & \\
\hline
\end{tabular}

${ }^{1} \mathrm{HP}=$ haptoglobin; PTGS2 $=$ cyclooxygenase-2; TNFA $=$ tumor necrosis factor $\alpha$; SAA1 = serum amyloid A-1; CCL5 = chemokine C-C motif ligand 5; NF-kB = nuclear factor kappa-light-chain enhancer of activated B cells.

${ }^{2}$ Treatment effect.

${ }^{*} P<0.05$ : increased compared with d 0 . 

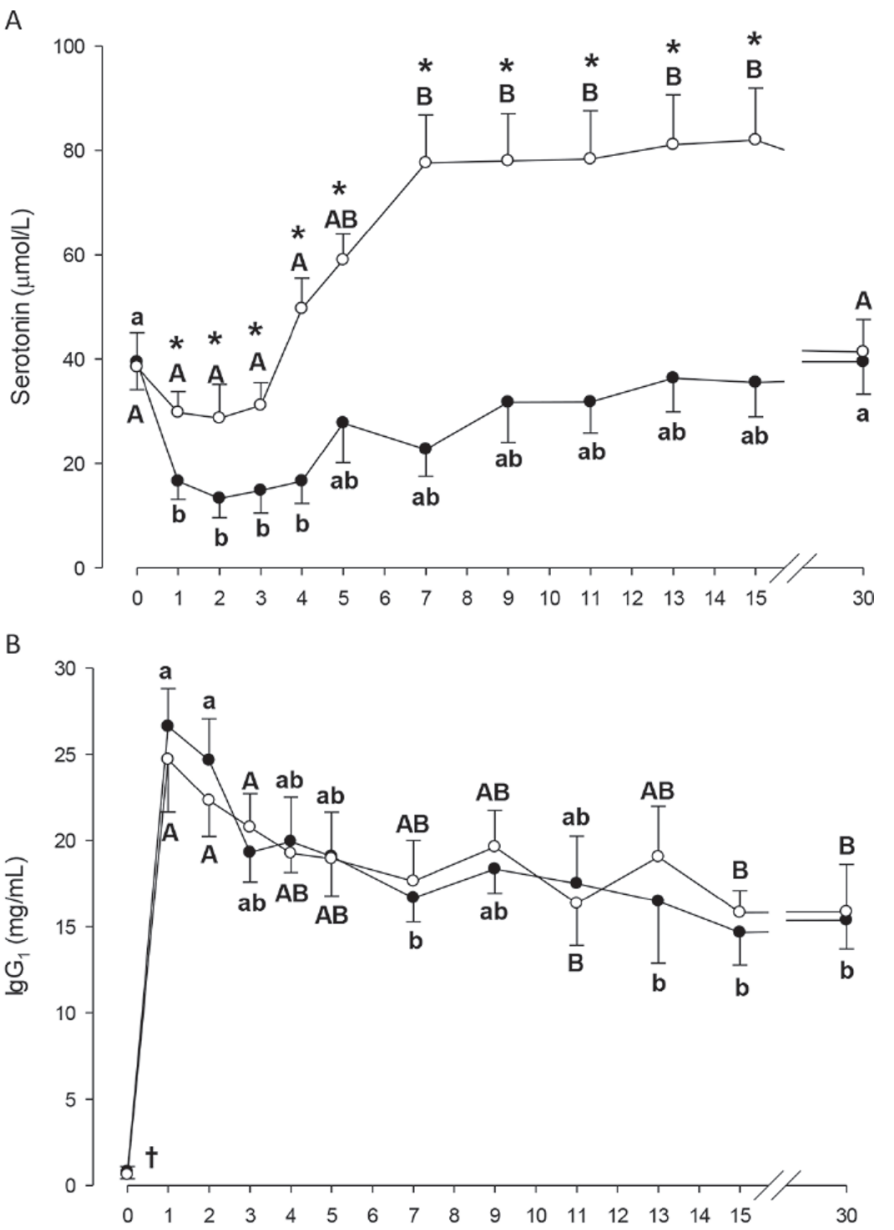

C

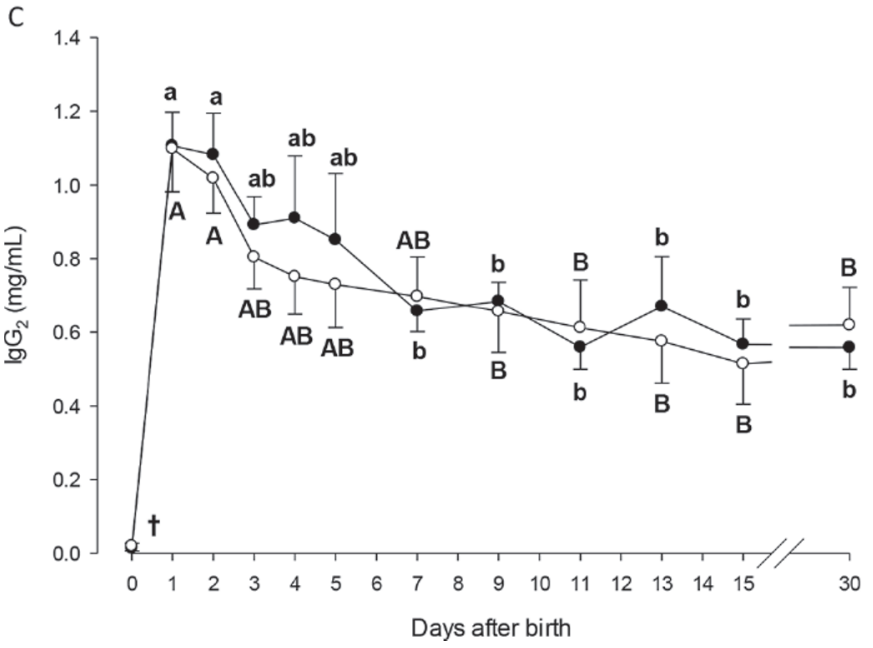

Figure 1. Serotonin (A), $\operatorname{IgG}_{1}(B)$, and $\operatorname{IgG}_{2}(C)$ concentrations of calves fed without 5-hydroxy-L-tryptophan (5-HTP) supplementation (control; $\bullet$ ) and calves fed with 5-HTP supplementation equivalent to $1.5 \mathrm{mg}$ of $5-\mathrm{HTP} / \mathrm{kg}$ of birth weight (5-HTP; O) during the experimental period. Different lowercase letters $(\mathrm{a}, \mathrm{b})$ indicate significant $(P<$ 0.05 ) differences between time points within control group. Different uppercase letters $(\mathrm{A}, \mathrm{B})$ indicate significant $(P<0.05)$ differences between time points within 5 -HTP group. * Significant $(P<0.05)$ difference between control and 5-HTP groups within each time point; †below detection limit (not statistically tested) we showed that supplementation of colostrum and milk with $1.5 \mathrm{mg}$ of $5-\mathrm{HTP} / \mathrm{kg}$ of birth weight induced a remarkable increase in serum 5 -HT concentrations.

In humans and mice, various immune cell types, such as monocytes, neutrophils, eosinophils, dendritic cells, mastocytes, macrophages, and natural killer (NK) cells, express 5-HT receptors (Ahern, 2011; Baganz and Blakely, 2013), in support of the assumption that 5-HT plays a role in the regulation of the immune system. In the present study, dietary 5-HTP supplementation during the first $15 \mathrm{~d}$ after birth and the resulting increase in 5-HT concentration did not lead to increased plasma IgG concentrations ( $\operatorname{IgG}_{1}$ and $\left.\operatorname{IgG}_{2}\right)$ during the first 30 $\mathrm{d}$ after birth. In calves, the efficient secretion of $\mathrm{IgG}$ by B lymphocytes occurs in wk 5 and 6 after calving (Jezek et al., 2009; Tizard, 2013), which could explain the results obtained in the present study.

From the selected target transcripts, dietary supplementation with 5-HTP increased the mRNA abundance of HP, PTGS2, IL-1 $\beta$, SAA1, CCL5, and NF-kB but not IL-8, IL-10, TNFA, IFN- $\alpha$, or IFN- $\beta$. Previous studies found that 5 -HT stimulates the production and secretion of IL-1 $\beta$ by macrophages through activation of NF-kB, which in addition enhances the phagocytic capacity of those macrophages via $5-\mathrm{HT}$ receptor $1 \mathrm{~A}$ (Freire-Garabal et al., 2003; Ghia et al., 2009). Active macrophages secrete PTGS2 (Feng et al., 1993; Phillips et al., 1993; Hinson et al., 1996), a key enzyme in the synthesis of prostaglandins such as $\mathrm{PGE}_{2}, \mathrm{PGF}_{2 \alpha}$, and $\mathrm{PGI}_{2}$ (Smith et al., 2000). These 3 prostaglandins play a central role in the generation of the inflammatory response (Ricciotti and FitzGerald, 2011). In addition, IL-1 $\beta$ secreted by macrophages stimulates the release of HP and SAA by hepatocytes into the bloodstream (Moshage, 1997) and CCL5 by diverse cells such as fibroblasts or endothelial cells (Selvan et al., 1998; Lebovic et al., 2001). Both HP and SAA are the most reactive acute phase proteins in ruminants (HernándezCastellano et al., 2014; Sikora et al., 2016). Thus, CCL5 mediates the activation of NK cells into chemokineactivated killer cells (Maghazachi et al., 1996). Thus, HP, SAA, and CCL5 are inflammatory chemoattractants for monocytes, lymphocytes, and granulocytes (Donlon et al., 1990; Maffei et al., 2009; Gouwy et al., 2015). Based on the results from the present study, 5-HTP supplementation may affect the innate and adaptive immune system in calves, potentially through macrophage stimulation and the consequent release of immune active substances.

Besides the immune system, 5-HT influences several metabolites related to glucose and lipid metabolism and alters calcium concentrations in dairy cows (Laporta et al., 2015; Weaver et al., 2016; HernándezCastellano et al., 2017a,b). However, equivalent results 
on newborn calves do not exist. In the present study, supplementation of 5-HTP did not affect glucose, fatty acids, calcium, or magnesium concentrations in blood. As described in mice, increased 5-HT concentrations cause elevated glucose and FA concentrations in blood (Sumara et al., 2012). Specifically, 5-HT stimulates gluconeogenesis in the liver in mice by acting on the 5 -HT receptor $2 \mathrm{~B}$, increasing the glucose concentration in blood. Thus, increased 5-HT concentrations enhance lipolysis in mice by signaling in adipocytes through the 5 -HT receptor $2 \mathrm{~B}$. Similar results were observed in cows, where the intravenous infusion of 5-HTP increased glucose and FA concentrations in late lactation (Laporta et al., 2015). In newborn calves, most of the energy is provided by colostrum and milk and not from the scarce adipose tissue (Danijela, 2015). The low capacity of those animals to mobilize energy from the adipose tissue could dampen the ability of 5-HTP to elevate glucose and fatty acids concentrations in these animals. Similarly, colostrum and milk are the main sources of calcium and magnesium for calves (Cupka, 1992). As no important differences in the milk replacer intake were observed between groups, we can assume that both groups of calves received the same amount of calcium and magnesium and that supplementation with 5-HTP did not interfere in the absorption of these 2 minerals.

In conclusion, 5-HTP supplementation during the first $15 \mathrm{~d}$ after birth increased 5-HT concentrations in blood without an effect on growth performance. The increased mRNA abundance of several immune factors indicates that the 5-HTP treatment might increase the immuno-protection of the calf against external agents.

\section{ACKNOWLEDGMENTS}

The expert performance of laboratory assays by Yolande Zbinden (Veterinary Physiology, Vetsuisse Faculty, University of Bern, Switzerland) is gratefully acknowledged.

\section{REFERENCES}

Ahern, G. P. 2011. 5-HT and the immune system. Curr. Opin. Pharmacol. 11:29-33.

Baganz, N. L., and R. D. Blakely. 2013. A dialogue between the immune system and brain, spoken in the language of serotonin. ACS Chem. Neurosci. 4:48-63.

Baumrucker, C. R., and R. M. Bruckmaier. 2014. Colostrogenesis: $\mathrm{IgG}_{1}$ transcytosis mechanisms. J. Mammary Gland Biol. Neoplasia 19:103-117.

Bendixen, E., M. Danielsen, K. Hollung, E. Gianazza, and I. Miller. 2011. Farm animal proteomics - A review. J. Proteomics 74:282293.

Blum, J. W., and H. Hammon. 2000. Colostrum effects on the gastrointestinal tract, and on nutritional, endocrine and metabolic parameters in neonatal calves. Livest. Prod. Sci. 66:151-159.
Boehme, S. A., F. M. Lio, L. Sikora, T. S. Pandit, K. Lavrador, S. P. Rao, and P. Sriramarao. 2004. Cutting edge: Serotonin is a chemotactic factor for eosinophils and functions additively with eotaxin. J. Immunol. 173:3599-3603.

Butler, J. E. 1973. Synthesis and distribution of immunoglobulins. J. Am. Vet. Med. Assoc. 163:795-798.

Cupka, P. 1992. The effects of age on the change in sodium, potassium and calcium levels in the blood-serum of calves. Zivocisna Vyroba $37: 125-134$.

Danijela, K. 2015. Endocrine and metabolic adaptations of calves to extra-uterine life. Acta Vet. 65:297.

Donlon, T. A., A. M. Krensky, M. R. Wallace, F. S. Collins, M. Lovett, and C. Clayberger. 1990. Localization of a human T-cell-specific gene, RANTES (D17s136e), to chromosome 17q11.2-q12. Genomics 6:548-553.

Erhard, M. H., P. Amon, M. Younan, Z. Ali, and M. Stangassinger. 1999. Absorption and synthesis of immunoglobulins G in newborn calves. Reprod. Domest. Anim. 34:173-175.

Evans, D. L., K. G. Lynch, T. Benton, B. Dube, D. R. Gettes, N. B. Tustin, J. P. Lai, D. Metzger, and S. D. Douglas. 2008. Selective serotonin reuptake inhibitor and substance $\mathrm{P}$ antagonist enhancement of natural killer cell innate immunity in human immunodeficiency virus/acquired immunodeficiency syndrome. Biol. Psychiatry 63:899-905.

Feng, L., W. Sun, Y. Xia, W. W. Tang, P. Chanmugam, E. Soyoola, C. B. Wilson, and D. Hwang. 1993. Cloning two isoforms of rat cyclooxygenase: Differential regulation of their expression. Arch. Biochem. Biophys. 307:361-368.

Freire-Garabal, M., M. J. Nunez, J. Balboa, P. Lopez-Delgado, R. Gallego, T. Garcia-Caballero, M. D. Fernandez-Roel, J. Brenlla, and M. Rey-Mendez. 2003. Serotonin upregulates the activity of phagocytosis through 5-HT1A receptors. Br. J. Pharmacol. 139:457-463.

Gendle, M. H., E. L. Young, and A. C. Romano. 2013. Effects of oral 5-hydroxytryptophan on a standardized planning task: Insight into possible dopamine/serotonin interactions in the forebrain. Hum. Psychopharmacol. 28:270-273.

Gershon, M. D., A. B. Drakontides, and L. L. Ross. 1965. Serotonin: Synthesis and release from the myenteric plexus of the mouse intestine. Science 149:197-199.

Ghia, J. E., N. Li, H. Q. Wang, M. Collins, Y. K. Deng, R. T. ElSharkawy, F. Cote, J. Mallet, and W. I. Khan. 2009. Serotonin has a key role in pathogenesis of experimental colitis. Gastroenterology 137:1649-1660.

Gouwy, M., M. De Buck, N. Portner, G. Opdenakker, P. Proost, S. Struyf, and J. Van Damme. 2015. Serum amyloid A chemoattracts immature dendritic cells and indirectly provokes monocyte chemotaxis by induction of cooperating CC and CXC chemokines. Eur. J. Immunol. 45:101-112.

Hernandez, L. L., S. W. Limesand, J. L. Collier, N. D. Horseman, and R. J. Collier. 2009. The bovine mammary gland expresses multiple functional isoforms of serotonin receptors. J. Endocrinol. 203:123-131.

Hernandez, M. E., D. Martinez-Fong, M. Perez-Tapia, I. Estrada-Garcia, S. Estrada-Parra, and L. Pavon. 2010. Evaluation of the effect of selective serotonin-reuptake inhibitors on lymphocyte subsets in patients with a major depressive disorder. Eur. Neuropsychopharmacol. 20:88-95.

Hernández-Castellano, L. E., A. M. Almeida, J. Renaut, A. Argüello, and N. Castro. 2016. A proteomics study of colostrum and milk from the two major small ruminant dairy breeds from the Canary Islands: A bovine milk comparison perspective. J. Dairy Res. 83:366-374.

Hernández-Castellano, L. E., A. M. Almeida, M. Ventosa, A. V. Coelho, N. Castro, and A. Arguello. 2014. The effect of colostrum intake on blood plasma proteome profile in newborn lambs: Low abundance proteins. BMC Vet. Res. 10:85.

Hernández-Castellano, L. E., A. Arguello, A. M. Almeida, N. Castro, and E. Bendixen. 2015a. Colostrum protein uptake in neonatal lambs examined by descriptive and quantitative liquid chromatography-tandem mass spectrometry. J. Dairy Sci. 98:135-147. 
Hernández-Castellano, L. E., L. L. Hernandez, H. Sauerwein, and R. M. Bruckmaier. 2017a. Endocrine and metabolic changes in transition dairy cows are affected by prepartum infusions of a serotonin precursor. J. Dairy Sci. 100:5050-5057.

Hernández-Castellano, L. E., A. Morales-delaNuez, D. Sanchez-Macias, I. Moreno-Indias, A. Torres, J. Capote, A. Arguello, and N. Castro. 2015b. The effect of colostrum source (goat vs. sheep) and timing of the first colostrum feeding ( $2 \mathrm{~h}$ vs. $14 \mathrm{~h}$ after birth) on body weight and immune status of artificially reared newborn lambs. J. Dairy Sci. 98:204-210.

Hernández-Castellano, L. E., S. R. Weaver, L. L. Hernandez, and R. M. Bruckmaier. 2017b. Increased serum serotonin improves parturient calcium homeostasis in dairy cows. J. Dairy Sci. 100:1580-1587.

Hinson, R. M., J. A. Williams, and E. Shacter. 1996. Elevated interleukin 6 is induced by prostaglandin E2 in a murine model of inflammation: Possible role of cyclooxygenase-2. Proc. Natl. Acad. Sci. USA 93:4885-4890.

Jezek, J., T. Malovrh, and M. Klinkon. 2009. Immunoglobulin dynamics with age in calves from farms in Slovenia. B. Vet. I. Pulawy. $53: 819-823$.

Kushnir-Sukhov, N. M., A. M. Gilfillan, J. W. Coleman, J. M. Brown, S. Bruening, M. Toth, and D. D. Metcalfe. 2006. 5-hydroxytryptamine induces mast cell adhesion and migration. J. Immunol. 177:6422-6432.

Laporta, J., S. A. Moore, S. R. Weaver, C. M. Cronick, M. Olsen, A. P. Prichard, B. P. Schnell, T. D. Crenshaw, F. Penagaricano, R. M. Bruckmaier, and L. L. Hernandez. 2015. Increasing serotonin concentrations alter calcium and energy metabolism in dairy cows. J. Endocrinol. 226:43-55.

Laporta, J., T. L. Peters, S. R. Weaver, K. E. Merriman, and L. L. Hernandez. 2013. Feeding 5-hydroxy-l-tryptophan during the transition from pregnancy to lactation increases calcium mobilization from bone in rats. Domest. Anim. Endocrinol. 44:176-184.

Lebovic, D. I., V. A. Chao, J. F. Martini, and R. N. Taylor. 2001. IL-1 beta induction of RANTES (regulated upon activation, normal T cell expressed and secreted) chemokine gene expression in endometriotic stromal cells depends on a nuclear factor-kappa B site in the proximal promoter. J. Clin. Endocrinol. Metab. 86:4759-4764.

Lehmann, M., S. K. Wall, O. Wellnitz, and R. M. Bruckmaier. 2015. Changes in milk L-lactate, lactate dehydrogenase, serum albumin, and IgG during milk ejection and their association with somatic cell count. J. Dairy Res. 82:129-134.

León-Ponte, M., G. P. Ahern, and P. J. O'Connell. 2007. Serotonin provides an accessory signal to enhance T-cell activation by signaling through the 5-HT7 receptor. Blood 109:3139-3146.

Lesurtel, M., R. Graf, B. Aleil, D. J. Walther, Y. H. Tian, W. Jochum, C. Gachet, M. Bader, and P. A. Clavien. 2006. Platelet-derived serotonin mediates liver regeneration. Science 312:104-107.

Maffei, M., M. Funicello, T. Vottari, O. Gamucci, M. Costa, S. Lisi, A. Viegi, O. Ciampi, G. Bardi, P. Vitti, A. Pinchera, and F. Santini. 2009. The obesity and inflammatory marker haptoglobin attracts monocytes via interaction with chemokine (C-C motif) receptor 2 (CCR2). BMC Biol. 7:87.

Maghazachi, A. A.. A. AlAoukaty, and T. J. Schall. 1996. CC chemokines induce the generation of killer cells from CD56(+) cells. Eur. J. Immunol. 26:315-319.
Mee, J. F. 2013. Why do so many calves die on modern dairy farms and what can we do about calf welfare in the future? Animals (Basel) 3:1036-1057.

Moshage, H. 1997. Cytokines and the hepatic acute phase response. J. Pathol. 181:257-266.

Phillips, T. A., D. A. Kujubu, R. J. MacKay, H. R. Herschman, S. W Russell, and J. L. Pace. 1993. The mouse macrophage activationassociated marker protein, p71/73, is an inducible prostaglandin endoperoxide synthase (cyclooxygenase). J. Leukoc. Biol. 53:411419.

Ricciotti, E., and G. A. FitzGerald. 2011. Prostaglandins and inflammation. Arterioscler. Thromb. Vasc. Biol. 31:986-1000.

Sauer, H., I. Mack, S. Kohler, S. Siegle, N. Rieber, S. Zipfel, B. Otto, Y. Ritze, S. C. Bischoff, and P. Enck. 2014. The effects of 5-hydroxytryptophan in combination with different fatty acids on gastrointestinal functions: A pilot experiment. Gastroenterol. Res. Pract. 2014:424503.

Selvan, R. S., H. B. Kapadia, and J. L. Platt. 1998. Complementinduced expression of chemokine genes in endothelium: regulation by IL-1-dependent and -independent mechanisms. J. Immunol. 161:4388-4395.

Serafeim, A., G. Grafton, A. Chamba, C. D. Gregory, R. D. Blakely, N. G. Bowery, N. M. Barnes, and J. Gordon. 2002. 5-Hydroxytryptamine drives apoptosis in biopsylike Burkitt lymphoma cells: Reversal by selective serotonin reuptake inhibitors. Blood 99:2545-2553.

Sikora, M., J. Krol, M. Nowak, T. Stefaniak, G. Aubertsson, and R. Kozdrowski. 2016. The usefulness of uterine lavage and acute phase protein levels as a diagnostic tool for subclinical endometritis in Icelandic mares. Acta Vet. Scand. 58:50.

Smith, W. L., D. L. DeWitt, and R. M. Garavito. 2000. Cyclooxygenases: Structural, cellular, and molecular biology. Annu. Rev. Biochem. 69:145-182.

Sugimoto, Y., I. Kimura, J. Yamada, Y. Watanabe, N. Takeuchi, and K. Horisaka. 1990. Effects of serotonin on blood glucose and insulin levels of glucose- and streptozotocin-treated mice. Jpn. J. Pharmacol. 54:93-96.

Sumara, G., O. Sumara, J. K. Kim, and G. Karsenty. 2012. Gutderived serotonin is a multifunctional determinant to fasting adaptation. Cell Metab. 16:588-600.

Tizard, I. R. 2013. Veterinary Immunology. Elsevier Health Sciences, Philadelphia, PA.

Watanabe, H., R. Saito, T. Nakano, H. Takahashi, Y. Takahashi, K. Sumiyoshi, K. Sato, X. Chen, N. Okada, S. Iwasaki, D. W. Harjanti, N. Sekiguchi, H. Sano, H. Kitazawa, M. T. Rose, S. Ohwada, K. Watanabe, and H. Aso. 2014. Effect of peripheral 5-HT on glucose and lipid metabolism in wether sheep. PLoS One 9:e88058.

Weaver, S. R., A. P. Prichard, E. L. Endres, S. A. Newhouse, T. L. Peters, P. M. Crump, M. S. Akins, T. D. Crenshaw, R. M. Bruckmaier, and L. L. Hernandez. 2016. Elevation of circulating serotonin improves calcium dynamics in the peripartum dairy cow. J. Endocrinol. 230:105-123.

Yamada, J., Y. Sugimoto, and M. Ujikawa. 2006. Involvement of leptin in hypophagia induced by the serotonin precursor 5-hydroxytryptophan (5-HTP) in mice. Biol. Pharm. Bull. 29:557-559. 